\title{
ANALISIS VARIABEL-VARIABEL YANG MEMPENGARUHI MINAT SISWA SMA MELANJUTKAN PENDIDIKAN KE PERGURUAN TINGGI
}

\author{
Mohaji Prianggita ${ }^{1}$, Muhammad Abdul Ghofur ${ }^{2}$ \\ ${ }^{1,2}$ Universitas Negeri Surabaya \\ 12ajiprianggita@gmail.com, ${ }^{2}$ muhammadghofur@unesa.ac.id
}

\begin{abstract}
Education is one of the essential assets in the development of society and the nation. The low percentage of people who study in Indonesia still needs to be explored. There are many reasons why students do not pursue their education in college. The purpose of this study was to analyze the influence of parents' socioeconomic interactions, self-efficacy, motivation, and student achievement on their interest in continuing education to college. This study uses a quantitative approach. Data was taken from 68 respondents majoring in Social Sciences at SMAN 1 Mejayan. The causal proof analysis performed using multiple linear regression equations. The results of the research prove a positive change in the variables of parents' socioeconomic status, selfefficacy, motivation, and student achievement towards the interest in continuing education. The implications of the results of this study are essential for teachers and school management always to increase student motivation and self-efficacy for students of lower socioeconomic status.
\end{abstract}

Keywords: Socioeconomic Status, Self Efficacy, Motivation, Academic Achievement, Interest.

\section{Pendahuluan}

Tingkat kemajuan negara bangsa selalu berhubungan dengan tingkat kualitas pendidikan yang diprogram dan diselenggarakan. Pendidikan harus terus dikembangkan seiring berjalannya zaman dari segi apapun. Pendidikan ada di sepanjang peradaban manusia untuk melestarikan sekaligus meningkatkan kualitas hidupnya. Usaha yang dapat jalankan untuk mendorong kualitas pendidikan utamanya melalui jalur lembaga pendidikan formal yaitu sekolah dasar sampai tinggi, serta pendidikan nonformal maupun informal. Lembaga pendidikan formal merupakan sebuah struktur jenjang kependidikan yang terdiri dari pendidikan tingkat dasar, tingkat menengah, dan pendidikan tingkat tinggi atau universitas (UU No 20 Tahun 2003). Jenjang lembaga pendidikan formal ini diselenggarakan dengan tujuan untuk meningkatkan pengetahuan, sikap, perilaku, bakat, mental dan kecerdasan seseorang.

Setiap pemerintahan suatu negara pasti berusaha untuk membangun sumber daya manusia yang kompeten dan berkualitas yang dilakukan melalui pendidikan. Sebagai sebuah negara yang besar, terutama dari segi wilayah geografis dan demografis mengelola pendidikan di Indonesia bukan hal yang mudah. Pada tahun 2010 indonesia menempati posisi keempat di seluruh dunia dengan kuantitas jumlah penduduk terbanyak (Badan Pusat Statistik, 2015). Education Development Index menyatakan bahwa negara Indonesia masih ada di tempat ke-69 dari total 127 negara. Indikator ini menandakan bahwa capaian Indonesia masih sangat jauh dari ideal.

Kontribusi tingkat pendidikan yang belum optimal secara kuantitatif salah satunya disumbangkan oleh lulusan sekolah tingkat menengah yang belum banyak melanjutkan ke pendidikan tinggi. Di Indonesia hanya sekitar $60 \%$ dari siswa sekolah menengah yang melanjutkan ke jenjang perkuliahan. Pendidikan menengah adalah pendidikan yang ditempuh untuk mempersiapkan siswa untuk melanjutkan ke pendidikan selanjutnya yaitu perkuliahan (Indriyanti, Siswandari, \& Ivada, 2013).

Berbagai upaya untuk mewujudkan tercapainya salah satu tujuan pendidikan menengah atas ke jenjang yang lebih tinggi sebenarnya telah dilakukan. Pemerintah telah mencanangkan berbagai program dan kebijakan agar siswa pendidikan menengah atas dapat berkuliah. Misalnya program beasiswa, besaran uang kuliah tunggal (UKT) rendah bagi siswa tidak

DOI: 10.33603/ejpe.v9i1.3519

This is an open access article under the CC-BY-SA license 
mampu, program bidik misi, dan kontrak kerja ketika setelah lulus dari perguruan tinggi. Namun pada kenyataannya siswa yang mendapatkan kesempatan pembelajaran di pendidikan tinggi masih belum optimal, walaupun beasiswa dan bantuan pemerintah tetap mengurangi peran biaya sebagai penghalang (Long \& Riley, 2007).

Banyak penyebab mengapa siswa tidak menjutkan pendidikannya ke perguruan tinggi. Secara umum hal tersebut dikarenakan faktor internal ataupun eksternal (Shaleh \& Wahab, 2004). Faktor intern bisa dikarenakan karena siswa tersebut kurang berminat untuk melanjutkan kuliah di perguruan tinggi. Sedangkan salah satu faktor eksternalnya adalah keluarga dan lingkungan sekitarnya yang tidak mendukung siswa dalam menempuh jenjang pendidikan lebih lanjut. Hal serupa terjadi di SMA Negeri 1 Mejayan dimana lulusan dari sekolah tersebut di jangka waktu periode 4 tahun sebelumnya pada data sekolah hanya $41 \%$ yang melanjutkan pendidikan ke perguran tinggi. Sisanya ada yang memilih bekerja selepas lulus dan ada juga yang masih belum menentukan langkah selanjutnya. Lulusan yang melanjutkan belajar di perguruan tinggi di dominasi oleh siswa dari jurusan IPA, sehingga penelitian yang akan dilakukan difokuskan hanya pada jurusan IPS saja.

Diperlukan adanya minat dari dalam diri siswa agar mereka dapat memotivasi dirinya untuk melanjutkan sekolah. Menurut Syah (2017) Keinginan terhadap sesuatu atau kegiatan tertentu dapat diartikan sebagai minat. Jadi minat berkuliah di pendidikan tinggi adalah sesuatu yang menarik dan mendorong mereka untuk berusaha. Siswa akan melakukan berbagai usaha seperti mengunjungi laman perguruan tinggi yang mereka inginkan dan ditambah dengan mencari informasi tentang program beasiswa di perguruan tinggi (Ibrahim \& Fachrurrozie, 2016). Kurangnya minat untuk berkuliah ke pendidikan tinggi sering dikarenakan oleh beberapa faktor diantaranya tingkat kesulitan tes masuk, kurangnya akses informasi yang diperoleh siswa mengenai prosedur dan jadwal melakukan pendaftaran, serta keadaan ekonomi keluarga yang tidak mendukung (Khoerunisa, 2014). Rendahnya ketertarikan untuk berkuliah ke jenjang pendidikan tinggi dapat disebabkan karena siswa tidak memiliki akses informasi baik dari perguruan tinggi maupun dari sekolahnya saat ini, sehingga siswa miskin persepsi utilitasnya (Durik, Shechter, Noh, Rozek, \& Harackiewicz, 2014). Siswa akan lebih tertarik ketika ada sosialisasi langsung daripada brosur atau pengumuan lewat website (Allen, Eby, \& Lentz, 2006). Hal ini sejalan dengan apa yang dinyatakan oleh Slameto (2010) bahwa rasa ketertarikan kepada sesuatu bisa dijadikan sebagai indikator minat.

Ada banyak faktor penyebab yang bisa menimbulkan kebimbangan siswa untuk berkuliah ke jenjang pedidikan tinggi. Shaleh dan Wahab (2004) mengemukakan ada 2 faktor yang menyebabkan siswa tidak melanjutkan pendidikannya yaitu faktor intrinsik dan ekstrinsik. Menurut Shaleh (2014) faktor ekstrinsik yang yang mempengaruhi siswa berasal dari masyarakat sekitar dan keluarga. Peran orang tua adalah faktor paling penting yang mempengaruhi pilihan sekolah seseorang siswa untuk maupun melanjutkan studi atau tidak (Altenhofen, Berends, \& White, 2016; Goldring \& Phillips, 2008). Hasil penelitian Kharisma (2013) mempelajari dimana status sosial ekonomi orang tua siswa bisa sangat menentukan keputusan siswa yang ingin berkuliah. Menurut Soekanto (2010) status sosio-ekonomi orang tua yang berdasar pada kriteria ekonomi, pendidikan, serta pekerjaan yang dimiliki orang tua. Aspek ekonomi menjadi sangat penting karena merupakan salah satu tumpuan utama dalam menjalani kehidupan sehari-hari (Ibrahim \& Fachrurrozie, 2016).

Menurut Amiqul \& Setiyani (2016) sebagian masyarakat Indonesia masih berada pada garis ekonomi di bawah ideal sehingga ini menjadi suatu permasalahan bagi pendidikan, karena sebagaimana diketahui pendidikan di Indonesia masih dirasa sangat mahal untuk masyarakat menengah ke bawah, terutama pendidikan tinggi. Masyarakat perlu menanggung biaya yang tidak sedikit bila mengharapkan anaknya mencapai pendidikan ke perguruan 
tinggi. Hurlock (2010) mengemukakan bahwa individu akan cenderung memperluas minat yang sebelumnya belum mampu untuk dieksekusi ketika kekuatan ekonomi individu tersebut membaik. Kekuatan ekonomi sosial orang tua juga akan mempengaruhi kualitas belajar pada anaknya, karena mengingat biaya yang dibutuhkan untuk melanjutkan ke pendidikan tinggi cukup banyak dan bisa sangat tinggi dalam hal proporsi pengeluaran kebutuhan mereka $(\mathrm{Li}$, 2007). Sehingga dengan kekuatan ekonomi yang tinggi akan mendukung keberlangsungan pendidikan seorang anak (Huang, Guo, Kim, \& Sherraden Michael, 2010; Steelman \& Powell, 1991).

Sekolah Menengah Atas disiapkan untuk menempuh pendidikan tinggi maka sebagian besar siswa cenderung akan melanjutkan pendidikannya ke perguruan tinggi, namun masalah ekonomi yang menjadi salah satu pertimbangan penting bagi mereka (Ibrahim \& Fachrurrozie, 2016). Karena sebagian finansial yang dibutuhkan oleh dirinya masih mengandalkan kekuatan ekonomi orang tua. Dengan status ekonomi yang mumpuni tentu tidak menjadi masalah untuk anaknya dapat menempuh jenjang pendidikan.

Selain masalah ekonomi, self efficacy juga sangat penting dalam pengambilan keputusan melanjutkan studi (Landry, 2003). Self efficacy ataupun keyakinan yang kurang akan kemampuan peserta didik itu sendiri maka ini akan berimbas terhadap cara mereka bereaksi pada problematika yang mereka alami. Menurut Bandura dalam Darmasaputro \& Gunawan (2018) self efficacy merupakan keyakinan atau kemampuan atas dirinya melakukan tugas atau usaha dalam mencapai hasil tertentu. Seseorang untuk dapat berpikir, cakap dalam berperilaku dan dapat memotivasi dirinya memerlukan tingkat kepercayaan diri yang cukup tinggi.

Siswa menganggap bahwa kecerdasan dan kekuatan finansial mereka kurang mumpuni untuk berkuliah yang nota bene memerlukan biaya yang tidak sedikit. Banyak juga mereka beranggapan bahwa hanya lulusan Sekolah yang bukan sekolah yang favorit. Hal ini selaras dengan hasil penelitian dari Astria (2006) dalam penelitiannya yang menunjukkan ada keterkaitan yang positif antara self efficacy dan minat agar dapat berkuliah.

Terdapat juga faktor intrinsik yang mempengaruhi ketertarikan siswa. Diantaranya faktor intrinsik tersebut adalah motivasi dan prestasi (Indriyanti \& Ivada, 2013). Menurut Sadiman (2011) motivasi bisa dipandang sebagai semua daya pendorong atau penggerak untuk melakukan sesuatu, sehingga tujuan dari suatu kegiatan dapat tercapai. Jadi Motivasi menimbulkan rasa ketertarikan dalam hal ini melanjutkan jenjang pendidikan. Menurut Hamalik (2012) motivasi yang tinggi yang dimilki seseorang akan mampu merangsang dirinya untuk mempunyai minat belajar yang tinggi sehingga dapat melanjutkan untuk berkuliah.

Menurut Hurlock (2010) terdapat faktor yang menyatakan bahwa yang menyebabkan ketertarikan terhadap pendidikan adalah prestasi belajar. Sedangkan menurut Mulyasa (2014) Prestasi belajar akademik merupakan sesuatu yang didapatkan oleh individu ketika mereka selesai menempuh kegiatan belajar. Hasil tersebut adalah nilai. Senada dengan penelitian Indriyanti (2013) yang menyebutkan bahwa prestasi belajar menyumbangkan pengaruh yang sangat besar terhadap minat untuk berkuliah. Begitu juga penelitian Fitriani (2014) yaitu ada kontribusi yang nyata antara prestasi pendidikan dan minat berkuliah. Sesuai dengan permasalahan yang terjadi tersebut penulis ingin melakukan penelitian mengenai pengaruh status sosial ekonomi orang tua, self efficacy, motivasi dan prestasi belajar terhadap keinginan untuk meneruskan pendidikan ke perguruan tinggi. 


\section{Metode Penelitian}

Jenis riset ini merupakan jenis riset kuantitatif. Menurut Sugiyono (2017), riset kuantitatif merupakan metode riset yang menjadikan filsafat positivisme sebagai dasarnya, yaitu digunakan untuk manganalisis populasi atau sampel yang telah ditentukan. Sedangkan teknik penentuan sampelnya sering dilakukan dengan acak, lalu data dikumpulkan melalui instrumen penelitian. Selanjutnya analisis data bersifat kuantitatif untuk menguji hipotesis yang telah ditetapkan sebelumnya. Responden dalam penelitian ini adalah siswa kelas XI IPS SMAN Mejayan yang berjumlah 68 orang. Kuisioner dan dokumentasi digunakan untuk mengumpulkan data.

Untuk memberikan gambaran tentang distribusi frekuensi kecondongan status sosial ekonomi orang tua, kemudian ditetapkan kategori penilaian menurut skor poin yang didapat dari hasil daftar pertanyaan sebagai berikut:

1) Menentukan bobot penilaian untuk variabel status sosial ekonomi orang tua pada setiap jawaban yang terdiri dari a (1), b (2), c (3), d (4), e (5).

2) Menghitung skor nilai setiap responden dengan cara menjumlahkan nilai skor yang diperoleh setiap responden dari 11 item pertanyaan.

3) Menentukan kelas interval dengan cara :

Kelas interval $=$

total skor tertinggi - total skor terendah

jumlah kategori

$$
\begin{aligned}
& =\frac{55-11}{3} \\
& =14,6 \sim 15
\end{aligned}
$$

Dengan demikian maka kategori penggolongan responden untuk variabel status sosial ekonomi orang tua adalah seperti disajikan pada tabel 1.

Tabel 1. Distribusi Frekuensi Kecenderungan Variabel Status Sosial Ekonomi Orang Tua

\begin{tabular}{ll}
\hline Kategori & Skor \\
\hline Status Sosial Ekonomi atas & $40-55$ \\
\hline $\begin{array}{l}\text { Status Sosial Ekonomi } \\
\text { Menengah }\end{array}$ & $25-39$ \\
\hline $\begin{array}{l}\text { Status Sosial Ekonomi } \\
\text { Bawah }\end{array}$ & $11-24$ \\
\hline
\end{tabular}

Uji Instrumen dalam penelitian ini adalah uji validitas dan uji reliabilitas. Uji validitas menunjukkan sampai dimana tingkat akurasi penerapan alat pengukuran pada indikasi yang akan diukur. Kuesioner disebut valid apabila tiap-tiap butir pertanyaan terdapat hubungan yang tinggi. Sebuah instrumen dikatakan reliabel jika instrumen itu digunakan untuk mengukur suatu entitas yang sama berkali-kali akan menunjukkan data yang sepadan. Uji reliabilitas memakai Cronbach Alpha dan dinyatakan reliabel apabila nilai Cronbach Alpha sebesar 0,7 sampai 0,8 (Kaplan \& Saccuzzo, 2001).

Uji Hipotesis mamakai model analisa regresi linier berganda yang di dalamnya ada Variabel Dummy, Uji t, Uji F dan Uji Koefisien Determinasi. Analisa Regresi Linier Berganda dipakai dengan tujuan agar diketahui pengaruh variabel independen pada variabel dependennya. Variabel dummy dipakai pada saat menemui variabel independen yang 
berskala non-metrik ataupun kategori. Kalau variabel independen merupakan variabel yang berformat kategori, maka dalam model analisis regresi variabel itu wajib dinyatakan sebagai variabel dummy dengan menggunakan kode 0 (nol) atau 1 (satu) sebagai dummy dari variabel kualitatif yang dianggap kuantitaif, sehingga berlaku penghitungan matematika.

Rumus penentuan jumlah variabel dummy adalah jumlah kategori dikurangi satu (n1)(Ghozali, 2016). Formulasi yang dihasikan dalam bentuk $Y=a+b_{1} D_{1}+b_{2} D_{2}+b_{3} X_{2}+b_{4}$ $\mathrm{X}_{3}+\mathrm{b}_{5} \mathrm{X}_{4}+\mathrm{e}$. Uji t digunakan untuk mengetahui besarnya pengaruh secara parsial atau secara sendiri-sendiri terhadap variabel dependen. Uji $\mathrm{F}$ digunakan agar diketahui besarnya pengaruh Status sosial ekonomi orang tua, self efficacy, motivasi, dan prestasi belajar secara simultan terhadap minat melanjutkan pendidikan ke perguruan tinggi. Uji Koefisien determinasi $\left(\mathrm{R}^{2}\right)$ untuk mendapatkan informasi tentang ukuran seberapa besar proporsi variasi dari variabel terikat dapat diterangkan oleh variabel bebasnya.

\section{Hasil dan Pembahasan}

\section{Analisis Regresi Linier Berganda dengan Variabel dummy}

Perangkat uji analisis statistik Regresi Linier Berganda ialah analisa yang digunakan untuk mengukur besarnya pengaruh variabel Status sosial ekonomi orang tua, self efficacy, motivasi, dan prestasi belajar terhadap minat melanjutkan pendidikan ke perguruan tinggi siswa SMAN 1 Mejayan. Setelah laksanakan proses olah data statistik didapat hasil seperti yang disajikan pada tabel 2 .

Tabel 2. Hasil Analisis Regresi linier Berganda dan Koefisien Regresi

\begin{tabular}{llllll}
\hline Model & B & Std. Error & Beta & t & Sig. \\
\hline (Constant) & 11.574 & 9.569 & & 1.210 & 0.231 \\
D1 SSE Atas & 4.032 & 1.434 & 0.323 & 2.812 & 0.007 \\
D2 SSE Menengah & 4.631 & 1.239 & 0.428 & 3.738 & 0.000 \\
Self Efficacy & 0.417 & 0.124 & 0.307 & 3.378 & 0.001 \\
Motivasi & 0.291 & 0.081 & 0.329 & 3.607 & 0.001 \\
Prestasi Belajar & 0.255 & 0.121 & 0.183 & 2.103 & 0.040 \\
\hline
\end{tabular}

Berlandaskan pada luaran penghitungan persamaan regresi dalam tabel di atas, sehingga dapat dinyatakan dalam persamaan sebagai berikut:

$\mathrm{Y}=11,574+4,032 \mathrm{D} 1+4,631 \mathrm{D} 2+0,417 \mathrm{X} 2+0,291 \mathrm{X} 3+0,255 \mathrm{X} 4+\mathrm{e}$

Keterangan :

$\mathrm{Y} \quad=$ Minat Melanjutkan Pendidikan ke Perguruan Tinggi

D1 = Dummy 1 Status Sosial Ekonomi orang tua (Atas)

D2 = Dummy 2 Status Sosial Ekonomi orang tua (Menengah)

$\mathrm{X} 2=$ Self Efficacy

$\mathrm{X} 3=$ Motivasi Belajar

$\mathrm{X} 4 \quad=$ Prestasi Belajar

\section{Uji Hipotesis}

Pengolahan data untuk menjawab hipotesis penelitian diperoleh luaran sebagai berikut. Hasil Uji t statistik diketahui Status Sosial ekonomi orang tua kategori Atas dan menengah dengan nilai $t_{\text {hitung }}=4,032$ dan 4,631 dan signifikansi $0,007<0,05$ dan $0,000<0,05$ maka Status Sosial ekonomi orang tua berpengaruh signifikan positif pada minat melanjutkan 
pendidikan ke perguruan tinggi. Hasil Uji t statistik diketahui self efficacy dengan nilai $t_{\text {hitung }}$ $=3,378$ dan signifikansi $0,001<0,05$ maka self efficacy berpengaruh positif terhadap minat melanjutkan pendidikan ke tingkat perguruan tinggi. Variabel motivasi dengan nilai $t_{\text {hitung }}=$ 3,607 dan signifikansi $0,001<0,05$ maka motivasi berpengaruh positif terhadap minat melanjutkan pendidikan ke perguruan tinggi. Serta variabel prestasi belajar dengan nilai $t_{\text {hitung }}$ $=2,103$ dan signifikansi $0,040<0,05$ maka prestasi belajar berpengaruh positif terhadap minat melanjutkan pendidikan ke perguruan tinggi. Sementara hasil uji statistik diketahui nilai $F_{\text {hitung }}=20,347$ dimana $F_{\text {tabel }}=2,515$ sehingga $F_{\text {hitung }}>F_{\text {tabel }}$ dengan signifikansi $0,000<$ 0,05 yang berarti Status Sosial ekonomi orang tua, self efficacy, motivasi, dan prestasi belajar berpengaruh positif terhadap minat melanjutkan pendidikan ke perguruan tinggi. Hasil analisis ini juga menunjukan koefisien determinasi $\left(\mathrm{R}^{2}\right)=0,591$ artinya $59,1 \%$ minat melanjutkan pendidikan ke tingkat universitas ditentukan oleh status sosial ekonomi orang tua, self efficacy, motivasi dan prestasi belajar, sedangkan sisanya sebesar 40,9\% dipengaruhi oleh variabel lain di luar model penelitian ini.

\section{Pengaruh Status Sosial Ekonomi Orang Tua Terhadap Minat Melanjutkan Pendidikan ke Perguruan Tinggi}

Dari hasil pengolahan data statistik menunjukkan sebagian besar siswa kelas XI IPS SMAN 1 Mejayan berdada pada keluarga dengan status sosial ekonomi orang tua dalam kategori cukup. Diketahui pada umunya orang tua yang anaknya sekolah di SMA memiliki harapan agar anaknya ketika tamat SMA nanti dapat meneruskan pendidikannya ke tingkat universitas. Melanjutkan pendidikan ke perguruan tinggi identik dengan dana yang mahal. Akan Tetapi karena saat ini sudah banyak beasiswa yang diberikan negara. Dengan demikian walaupun status sosial ekonomi orang tuanya cenderung menengah ke bawah, namun secara indipenden status sosial ekonomi orang tua juga menentukan minat melanjutkan sekolah ke tingkat universitas yang cukup besar. Ketika siswa berasal dari keluarga dengan status sosial ekonomi yang lebih tinggi maka minat mereka untuk melanjutkan jenjang pendidikan lebih tinggi dibanding dengan siswa dari keluarga dengan status sosial ekonomi di bawahnya.

Hasil ini sepandangan dengan simpulan penelitian Ekpo \& Ajake (2013) yang menerangkan dimana status sosial ekonomi keluarga siswa menentukan tingkat pendidikan siswa tersebut. Masalah tingkat status sosial ekonomi orang tua pada akhirnya akan menimbulkan problem tersendiri bagi orang tua untuk menentukan beberapa pilihan terhadap kelanjutan sekolah anak-anaknya. Sehingga tinggi rendahnya minat anak belajar sangat dipengaruhi oleh status sosial eknomi orang tuanya. Status sosial ekonomi orang tua yang baik akan mendukung anaknya memperluas minatnya, salah satunya dalam melanjutkan pendidikan ke perguruan tinggi. Walaupun status sosial ekonomi orang tua mempunyai pengaruh signifikan pada pendidikan anak (Fruehwirth \& Gagete-Miranda, 2019), namun pada penelitian ini membuktikan adanya pengaruh pada minat siswa untuk menruskan sekolahnya ke pendidikan tinggi.

\section{Pengaruh Self Efficacy Terhadap Minat Melanjutkan Pendidikan ke Perguruan Tinggi}

Hasil Uji t statistik diketahui self efficacy dengan nilai $\mathrm{t}_{\text {hitung }}=3,378>\mathrm{t}_{\text {tabel }}=2,051$ dan signifikansi 0,001 <0,05 yang menunjukan bahwa self efficacy berpengaruh positif terhadap minat melanjutkan pendidikan ke perguruan tinggi. Hal ini sejalan dengan penjelasan yang disampaikan oleh Luthans (Inhad, 2014) bahwa self efficacy akan mempengaruhi seperti apa individu merasakan, berpikir, memotivasi diri sendiri serta bertingkah laku. Berdasarkan ulasan itu bisa diartikan bahwa self efficacy akademik yang dimiliki oleh siswa mempunyai pengaruh pada minat siswa dalam hal ini minat untuk meneruskan studi siswa kejenjang yang 
lebih tinggi. Oleh sebab itu siswa diharapkan mempunyai tingkat self efficacy yang tinggi bila memiliki hasrat meneruskan studi ke perguruan tinggi.

Seseorang yang mempunyai self efficacy tinggi memercayai kalau dirinya sanggup untuk melaksanakan aktivitas yang akan dilakukannya. Kebalikannya, seseorang yang memiliki self efficacy rendah tidak percaya akan kemampuannya dalam melakukan sebuah aktivitas. Self efficacy akademik ialah salah satu aspek yang mempunyai pengaruh pada minat meneruskan sekolah. Rendahnya self efficacy akademik yang dimiliki siswa berhubungan erat dengan minat siswa untuk meneruskan pendidikannya. Penelitian ini selaras dengan penelitian Astria (2006) dan Lestari \& Yulianto (2017) yang menyatakan bahwa Self Efficacy berpengaruh terhadap minat melanjutkan ke perguruan tinggi.

\section{Pengaruh Motivasi Terhadap Minat Melanjutkan Pendidikan ke Perguruan Tinggi}

Hasil analisis data menunjukkan sebagian besar siswa kelas XI IPS SMAN 1 Mejayan memiliki motivasi yang tinggi. Hal ini mengindikasikan bahwa siswa kelas XI IPS SMAN 1 Mejayan telah mempunyai kesadaran akan pentingnya belajar. Siswa memiliki ketekunan dalam belajar dan aktif dalam setiap proses belajar mengajar di kelas, menunjukkan adanya minat dan antusias terhadap materi yang telah dipelajari dalam belajar, mampu menyelesaikan latihan dan tugas yang diberikan oleh guru dengan baik. Bila di dalam diri siswa itu memiliki motivasi yang tinggi, maka dia akan mengeluarkan segala kapasitas dan kemampuannya untuk memperoleh hasil yang terbaik dalam belajarnya, termasuk untuk dapat meneruskan pendidikan ke perguruan tinggi yang diminatinya.

Hasil Uji $\mathrm{t}$ statistik variabel motivasi dengan nilai $\mathrm{t}_{\text {hitung }}=3,607>\mathrm{t}_{\text {tabel }}=2,051$ dan signifikansi $0,001<0,05$ maka motivasi berpengaruh positif terhadap minat melanjutkan pendidikan ke perguruan tinggi. Dengan begitu bisa disimpulkan, makin tinggi tingkat motivasi maka makin tinggi minat meneruskan belajar ke tingkat universitas. Hal ini pun berlaku untuk hal sebaliknya yakni bila motivasi rendah maka makin kecil minat meneruskan perguruan tinggi. Hal ini selaras dengan penelitian Kharisma (2013) bahwa terdapat pengaruh positif motivasi terhadap minat melanjutkan pendidikan ke perguruan tinggi. Salah satu faktor yang mempengaruhi tumbuh kembangnya minat seseorang pada suatu hal adalah motivasi dan cita-cita. Jadi motivasi memicu suatu kemauan dan rasa ketertarikan untuk meneruskan pendidikan ke perguruan tinggi. Menurut usulan Hamalik (2012) bahwa prinsip motivasi dapat mendorong minat siswa untuk belajar. Dengan adanya motivasi yang tinggi, siswa bisa memiliki hasrat belajar yang baik pula sampai pada level maksimal yang dia inginkan, salah satunya adalah belajar ke jenjang universitas.

\section{Pengaruh Prestasi Belajar Terhadap Minat Melanjutkan Pendidikan ke Perguruan Tinggi}

Prestasi belajar pada penelitian ini diukur dengan rerata dari nilai rapor semua mata pelajaran siswa kelas XI IPS SMAN 1 Mejayan dari kelas satu sampai kelas 2 semester gasal 2019/2020. Jadi rata-rata nilai semester yang telah ditempuh oeh siswa selama di SMAN 1 Mejayan. Nilai yang diberikan oleh seorang pengajar ini termasuk aspek kognitif, afektif serta psikomotorik siswa. Berdasarkan hasil analisis deskriptif, prestasi belajar siswa kelas XII kompetensi keahlian akuntansi memiliki predikat kompeten. Rata - rata nilai rapor seluruh mata pelajaran siswa kelas XII IPS SMAN 1 Mejayan mencapai nilai 87. Sehingga dapat disimpulkan bahwa minimal rerata nilai rapor semua mata pelajaran siswa kelas XII kompetensi keahlian akuntansi di SMAN 1 Mejayan sudah mencapai Kriteria Belajar Minimal (KBM). 
Hasil Uji t statistik variabel prestasi belajar dengan nilai $t_{\text {hitung }}=2,103$ dan signifikansi $0,040<0,05$ maka prestasi belajar berpengaruh positif terhadap minat melanjutkan pendidikan ke perguruan tinggi. Hal Senada juga dalam penelitian Indriyanti (2013) yang menyatakan dimana faktor yang menentukan minat melanjutkan ke jenjang universitas adalah prestasi belajar. Begitu juga penelitian Khoerunisa (2014) yaitu prestasi belajar memiliki pengaruh yang positif terhadap minat melanjutkan pendidikan ke tingkat universitas.

Pengaruh antara Status Sosial Ekonomi Orang tua, Self Efficacy, Motivasi, dan prestasi belajar Terhadap Minat Melanjutkan Pendidikan ke Perguruan Tinggi

Hasil uji statistik diketahui nilai $F_{\text {hitung }}=20,347$ dimana $F_{\text {tabel }}=2,515$ sehingga $F_{\text {hitung }}>$ $F_{\text {tabel }}$ dengan signifikansi $0,000<0,05$ yang berarti Status Sosial ekonomi orang tua, self efficacy, motivasi, dan prestasi belajar secara bersama-sama berpengaruh positif terhadap minat melanjutkan pendidikan ke perguruan tinggi. Hasil peneltian juga menunjukan koefisien determinasi $\left(\mathrm{R}^{2}\right)=0,591$ artinya $59,1 \%$ minat melanjutkan pendidikan ke perguruan tinggi dapat dipengaruhi status sosial ekonomi orang tua, self efficacy, motivasi dan presitasi belajar. Sisanya 40,9\% dipengaruhi oleh faktor lain.

Penelitian ini memperkuat penelitian yang dilakukan Herdiyani (2018) Apabila terdapat efek motivasi belajar serta status sosial ekonomi orang tua pada minat meneruskan studi ke perguruan tinggi siswa sebesar $31,9 \%$. Ini berarti makin positif motivasi belajar dan status ekonomi orang tua maka kian tinggi minat meneruskan sekolah ke perguruan tinggi. Hal senada juga diungkapkan oleh Darmawan (2017) bahwa status sosial ekonomi dan lingkungan teman sebaya berpengaruh positif terhadap minat meneruskan sekolan ke tingkat pendidikan tinggi.

Implikasi dari hasil penelitian ini adalah bahwa self efficacy, motivasi, dan hasil belajar penting bagi peningkatan peluang siswa untuk melanjutkan jenjang pendidikannya. Pembelajaran dan lingkungan sekolah perlu untuk memperhatikan upaya peningkatan ketiga variabel ini. Guru sebagai ujung tombak pembelajaran di sekolah perlu untuk selalu berupaya memotivasi siswa sembari meingkatkan kualitas pembelajarannya. Bagi siswa dari status sosial ekonomi bawah juga perlu untuk mendapat perhatian khusus terutama dalam hal peningkatan motivasi.

\section{Simpulan}

Berlandaskan pada hasil peneltitian yang telah dilakukan, maka dapat ditarik sebuah simpulan dimana status sosial ekonomi orang tua, self efficacy, motivasi, dan prestasi belajar berpengaruh positif secara parsial dan simultan terhadap minat melanjutkan pendidikan ke perguruan tinggi siswa SMAN 1 Mejayan. Maka berdasarkan hasil penelitian ini untuk siswa SMAN 1 Mejayan diharapkan untuk tidak cepat merasa puas atas hasil yang telah dicapai. Harus terus belajar dan mengerjakan tugas-tugas yang diberikkan untuk menambah wawasan dan kemampuan. Sehingga dapat meningkatkan prestasi belajarnya. Sementara untuk guru hendaknya ketertarikam siswa dalam maneruskan tingkat pendidikan yang lebih tinggi senantiasa di dorong. Hal ini dapat dilakukan dengan cara memotivasi dan mendorong siswa agar terus menuntut ilmu dan menambah wawasan dalam pendidikan tinggi. Dengan tingkat pendidikan yang tinggi siswa akan merasa bahwa dirinya mempunyai bekal yang akan digunakan untuk bertahan hidup.

Untuk siswa dengan status sosial ekonomi rendah ataupun tingkat penghasilan orang tua terhitung rendah, sekiranya gairah siswa dan minat untuk meneruskan pendidikan ke 
perguruan tinggi senantiasa diupayakan dan disupport sepenuhnya oleh lingkungan sekolah, sebab saat ini telah banyak pilihan-pilhan lain untuk mendukung dana pendidikan semacam beasiswa pendidikan yang diberikan oleh universitas, maupun yang berasal dari kebijakan negara dan beberapa perusahaan dengan program tanggung jawab sosialnya.

\section{Referensi}

Allen, T. D., Eby, L. T., \& Lentz, E. (2006). The Relationship Between Formal Mentoring Program Characteristics and Perceived Program Effectiveness. Personnel Psychology, 59(1), 125-153. https://doi.org/10.1111/j.1744-6570.2006.00747.x

Altenhofen, S., Berends, M., \& White, T. G. (2016). School Choice Decision Making Among Suburban, High-Income Parents. AERA Open, 2(1), 233285841562409. https://doi.org/10.1177/2332858415624098

Amiqul, M., \& Setiyani, R. (2016). Pengaruh Prestasi Belajar, Kondisi Sosial Ekonomi Orang Tua dan Self Efficacy Terhadap Minat Melanjutkan Studi Ke Perguruan Tinggi Siswa IPS. Economic Education Analysis Journal, 5(3).

Astria, T. (2006). Hubungan antara Self Efficacy dengan minat melanjutkan studi ke perguruan tinggi pada siswa SMA Negeri 2 Ciamis. Universitas Ahmad Dahlan.

BPS. (2015). Badan Pusat Statistik.

Darmasaputro, A., \& Gunawan, W. (2018). Hubungan Efikasi Diri Pengambilan Keputusan Karir dan Pengambilan Keputusan Karir pada Siswa SMA. Jurnal Psikologi.

Darmawan, I. (2017). Pengaruh Status Sosial Ekonomi Dan Lingkungan Teman Sebaya Terhadap Minat Melanjutkan Studi Ke Perguruan Tinggi Pada Peserta didik Di Sma N 1 Bayat. Universitas Negeri Yogyakarta.

Durik, A. M., Shechter, O. G., Noh, M., Rozek, C. S., \& Harackiewicz, J. M. (2014). What if I can't? Success expectancies moderate the effects of utility value information on situational interest and performance. Motivation and Emotion, 39(1), 104-118. https://doi.org/10.1007/s11031-014-9419-0

Ekpo, T. E., \& Ajake, U. E. (2013). Family Socio-Economic Status and Delinquency among Senior Secondary School Students in Calabar South, Cross River State, Nigeria. American International Journal of Contemporary Research.

Fruehwirth, J. C., \& Gagete-Miranda, J. (2019). Your peers' parents: Spillovers from parental education. Economics of Education Review, 73, 101910. https://doi.org/10.1016/j.econedurev.2019.101910

Ghozali, I. (2016). Aplikasi Analisis Multivariete dengan Program IBM SPSS 23 (8th ed.). Semarang: Badan Penerbit Universitas Diponegoro.

Goldring, E. B., \& Phillips, K. J. R. (2008, May). Parent preferences and parent choices: The public-private decision about school choice. Journal of Education Policy, Vol. 23, pp. 
209-230. https://doi.org/10.1080/02680930801987844

Hamalik, O. (2012). Kurikulum dan Pembelajaran. Jakarta: Bumi Aksara.

Herdiyani, R. (2018). Pengaruh Motivasi Belajar Dan Status Sosial Ekonomi Orang Tua Terhadap Minat Melanjutkan Studi Ke Perguruan Tinggi Peserta didik Kelas Xii Ips Semester Genap Sma Perintis 2 Bandar Lampung Tahun Pelajaran 2015/ 2016.

Huang, J., Guo, B., Kim, Y., \& Sherraden Michael, M. (2010). Parental income, assets, borrowing constraints and children's post-secondary education. Children and Youth Services Review, 32(4), 585-594. https://doi.org/10.1016/j.childyouth.2009.12.005

Hurlock. (2010). Perkembangan Anak Jilid 2. Jakarta: Erlangga.

Ibrahim, M. W., \& Fachrurrozie, F. (2016). Pengaruh Efikasi Diri, Kondisi Sosial Ekonomi Orang Tua, dan Bimbingan Karir Terhadap Motivasi Melanjutkan Pendidikan Ke Perguruan Tinggi. Economic Education Analysis Journal, 5(2), 416-427.

Indriyanti. (2013). Faktor-Faktor yang Memengaruhi Minat Melanjutkan Pendidikan ke Perguruan Tinggi pada Siswa Kelas XII Akuntansi SMK Negeri 6 Surakarta tahun 2013. Jurnal Penelitian UNS, 1, 1-10.

Indriyanti, N., \& Ivada, E. (2013). Faktor-Faktor yang Memengaruhi Minat Melanjutkan Pendidikan ke Perguruan Tinggi Pada Siswa Kelas XII Akuntansi SMK Negeri 6 Surakarta 2013. Jupe UNS, 1(2), 1-10.

Indriyanti, N., Siswandari, \& Ivada, E. (2013). FAKTOR-FAKTOR YANG MEMENGARUHI MINAT MELANJUTKAN PENDIDIKAN KE PERGURUAN TINGGI PADA SISWA KELAS XII AKUNTANSI SMK NEGERI 6 SURAKARTA TAHUN 2013. Jupe UNS.

Inhad, S. (2014). Upaya Meningkatkan Efikasi Diri Akademik Melalui Diskusi Kelompok Pada Siswa Kelas VIII A di SMP Negeri 3 Bukateja Purbalingga. Jurnal Riset Mahasiswa Bimbingan Dan Konseling, 4(1).

Kaplan, R. M., \& Saccuzzo, D. P. (2001). Psychological testing: Principles, applications, and issues (5th ed.). Thomson Learning.

Kharisma, N., \& Latifah, L. (2013). Pengaruh Motivasi, Prestasi Belajar, Status Sosial Ekonomi Orang Tua dan Lingkungan Teman Sebaya Terhadap Minat Melanjutkan Pendidikan Ke Perguruan Tinggi Pada Siswa Kelas XII Kompetensi Keahlian Akuntansi Di SMK Negeri Se-Kota Semarang Tahun Ajaran 2014/. Economic Education Analysis Journal, 3(1), 833-846.

Khoerunisa, F. (2014). Pengaruh Motivasi, Prestasi Belajar, Status Sosial Ekonomi Orang Tua dan Lingkungan Sekola hterhadap Minat Melanjutkan ke Perguruan Tinggi pada Siswa Kelas XII Akutansi SMK Negeri 1 Kendal. Economic Education Analysis Journal.

Landry, C. (2003). Self-efficacy, motivation, and outcome expectation correlates of college students' intention certainty. LSU Doctoral Dissertations. Retrieved from https://digitalcommons.lsu.edu/gradschool_dissertations/1254 
Lestari, R. A. P., \& Yulianto, A. (2017). Pengaruh Efikasi diri, lingkungan Sosial, Akses kepada modal, dan Kepemilikan jaringan sosial Terhadap Sikap Kewirausahaan Mahasiswa Program Studi Pendidikan Akuntansi Angakatan 2013 Universitas Negeri Semarang. Economic Education Analysis Journal.

Li, W. (2007). Family background, financial constraints and higher education attendance in China. Economics of Education Review, 26(6), 724-734. https://doi.org/10.1016/j.econedurev.2007.09.001

Long, B. T., \& Riley, E. (2007). Financial aid: A broken bridge to college access? Harvard Educational Review, 77(1), 39-63. https://doi.org/10.17763/haer.77.1.765h8777686r7357

Mulyasa. (2014). Pengembangan dan Implementasi Kurikulum 2013. Bandung: Remaja Rosdakarya.

Presiden Republik Indonesia. Undang-Undang Republik Indonesia Nomor 20 Tahun 2003 Tentang Sistem Pendidikan Nasional. , (2003).

Sadirman. (2011). Interaksi dan Motivasi Belajar Mengajar. Jakarta: Rajagrafindo Persada.

Shaleh, A. R. (2014). Psikologi Suatu Pengantar Dalam Perspektif Islam. Jakarta: Prenada Media.

Shaleh, A. R., \& Wahab, M. A. (2004). Psikologi Suatu Pengantar Dalam Perspektif Islam. Jakarta: Prenada Media.

Slameto. (2010). Belajar dan Faktor-Faktor yang Mempengaruhi. Jakarta: Rineka Cipta.

Soekanto, S. (2010). Sosiologi Suatu Pengantar. Jakarta: Rajawali Pers.

Steelman, L. C., \& Powell, B. (1991). Sponsoring the Next Generation: Parental Willingness to Pay for Higher Education. American Journal of Sociology, 96(6), 1505-1529. https://doi.org/10.1086/229695

Sugiyono. (2017). Metode Penelitian Kuantitatif, kualitatif, dan $R \& G$. Bandung: Alfabeta. Syah, M. (2017). Psikologi Pendidikan dengan Pendekatan Baru. Bandung: Rosdakarya. 